\title{
Strategy, Careers, and Judicial Decisions: Lessons from the Bolivian Courts
}

\author{
Aníbal Pérez-Liñán University of Pittsburgh \\ Barry Ames University of Pittsburgh \\ Mitchell A. Seligson Vanderbilt University
}

Using survey data from Bolivian trial courts, we explore the relationship between judicial decisions, career goals, and hierarchical pressures in continental legal systems. Based on a principal-agent approach, we hypothesize that inferior court judges are more likely to defer to superior courts when they share their interpretation of the law, when they anticipate reversals, and when they fear political manipulation of judicial careers. In turn, superior judges are likely to exercise informal pressures over inferior court judges who deviate from the former's legal views and do not anticipate their preferences. The conclusions emphasize the utility of survey research for the study of strategic compliance in judicial institutions.

W hat are the sources of judicial independence in trial courts? Under what conditions may superior courts influence the decisions of lower-level judges? These questions are critical to our ability to understand issues of separation of powers and access to justice in new democracies. Hierarchical control over trial courts is often manipulated to derail investigations against powerful political actors (Chavez 2003) or to impose ideological biases on the judicial process (Hilbink 2003). At the same time, perceptions of an unfair legal process may discourage common citizens' use of, or compliance with, the legal system (Seligson 2002a; Tyler 2001).

Neo-institutional studies of judicial behavior emphasize that judges behave strategically and that institutional settings shape their decisions (Brace and Hall 1997; Epstein and Knight 1998; Hall 1992; Iaryczower, Spiller, and Tommasi 2002; Scribner 2003). Studies applying this approach to courts in new democracies have yielded valuable insights (Chavez 2003; Helmke 2002). Still, much of this research focuses on courts of last resort-supreme courts or constitutional tribunals-and usually makes two powerful assumptions: that judges have static ambitions, and that elected politicians can appoint or dismiss judges, thus influencing the judicial process. ${ }^{1}$

While these assumptions are appropriate for the study of superior courts, they may need to be qualified in the study of lower-level courts. Prior research has suggested that progressive ambitions are relevant to understand the behavior of lower-level judges (Cohen 1991; Ramseyer and Rasmusen 2001) and that principal-agent relations more often refer to interactions within the judicial hierarchy than to interactions across branches of government (Benesh and Reddick 2002; Brent 2003; Haire, Lindquist, and Songer 2003; Songer, Segal, and Cameron 1994). ${ }^{2}$ The latter problem is particularly relevant in the Andean region, where most countries (Bolivia, Colombia, Ecuador, and Peru) reformed their constitutions in the 1990s to appoint trial court judges without any direct intervention of the executive or legislature. ${ }^{3}$

\footnotetext{
${ }^{1}$ For U.S. State Supreme Courts, the electorate is another prominent source of influence over strategic behavior (Hall 2001).
}

${ }^{2}$ This does not necessarily mean that executive officials or legislators do not exercise influence over trial courts. It may simply mean that they employ indirect hierarchical channels to transmit their demands to the judges.

${ }^{3}$ In Colombia and Ecuador even candidates for the Supreme Court have been recruited by the incumbent justices without the intervention of elected politicians. But in Ecuador, the system of autonomous recruitment collapsed in late 2004, when President Gutierrez's congressional coalition removed, by a simple majority, all 31 Supreme Court justices. President Gutierrez attempted to dismiss the new Court by decree a few months later, triggering protests that led to his removal in April of 2005.

The Journal of Politics, Vol. 68, No. 2, May 2006, Pp. 284-295 
This article utilizes a principal-agent approach to interpret hierarchical relations in judicial bodies. Our model emphasizes how judges' career ambitions shape their understanding of judicial independence and how superior judges respond strategically by deciding when to exercise informal pressures over trial courts. We test the model using survey data on the Bolivian judiciary. The analysis shows that judges are less likely to defer to superior courts (and thus more likely to be the target of pressures) when they disagree with the superior courts' interpretation of the law, and they are more likely to anticipate the preferences of superior courts when they fear reversals and the manipulation of promotions.

\section{Strategic Ruling in Civil Law Systems}

In the continental legal tradition, the text of the positive law is presumed to be the fundamental source of law. ${ }^{4}$ This means that courts must rule within the boundaries of legal interpretation imposed by the text of statutes rather than by interpretations imposed by tradition and precedent (David and Brierley 1978; Merryman 1985). The civil law system therefore entails a distinctive view of judicial independence as administrative discretion. ${ }^{5}$ We claim that the positions adopted by judges within this range of discretion are determined not only by their legal interpretation of cases, but also by their career ambitions and by the probability that a superior court will overturn their decisions.

Our model of judicial ruling involves two players: a judge and a superior court with authority to act as a veto player (to overturn the judge) or as a "sanctioning player" (able or to deny the judge a promotion; Helmke 2003). Both the judge and the court have preferences with regards to the interpretation of a particular piece of legislation. For simplicity, we assume this range of legal interpretation to be onedimensional, with J representing the judge's preferred ruling in a case and SC being the ideal point of the

\footnotetext{
${ }^{4}$ The 1794 Prussian and the 1855 Chilean Civil Codes, for instance, explicitly prevented judges from interpreting the spirit of the law (Hilbink 2003).

${ }^{5}$ Article 116 of the Bolivian Constitution, for example, proclaims that: "Magistrates and judges are independent when administering justice and they are not bounded except by the Constitution and the law." In the Japanese version: "All judges are independent in the exercise of their conscience and bound only by this constitution and the laws" (Art. 76, Sec. 3). See Ramseyer and Rasmusen (2001, 333).
}

pivotal member of the superior court. Judges know the location of SC in two ways: directly, if a member of the superior court discusses a legal case with them, or indirectly, through the position of the court in prior rulings.

The game unfolds in two moments. During the first stage, the pivotal judge in the superior court decides whether to disclose his or her preferences in a case to a lower judge in charge of the decision. Although this communication can efficiently convey the position of the superior court, it is not free of risks, because it constitutes an informal procedure that may lead to the superior judge being charged with improper behavior. In contrast to the ex-post reversal of decisions, which is a form of public signaling open to the legal community, informal contacts represent an exante form of private information that is professionally questionable and many times simply illegal. As a result, superior judges who engage in informal contacts must do so with great care, targeting judges who are likely to rule in the wrong direction unless properly directed.

During the second moment, the lower judge makes a decision $R$ within the range allowed by law, either deferring to the superior court's preferences or defying them to impose an independent interpretation of the law. At this point the payoffs are disclosed: the superior judge is punished (or not) for any attempts to put pressure on the trial court, and the lower judge finds out whether the superior court will uphold or overturn the decision (in the latter case imposing $R^{\prime}=S C$ ) and whether the outcome of the case will affect his or her career. Figure 1 summarizes the game in extensive form and presents the expected payoffs for each player.

Policy Goals. In Figure 1, the two players have policy goals (broadly defined to include preferences over particular interpretations of the law) and career goals (static and/or progressive ambitions). Let $d$ be the spatial distance between the players, $d=|J-S C|$. The cost of a legal decision $R$ for the superior judge is defined as $w_{s} D_{s}$, where $w_{s}$ is a nonnegative function indicating the strength of the superior judge's preferences, and $D_{s}=|R-S C|$, i.e., $D_{s}=0$ if the ruling reflects the superior judge's preference and $\mathrm{D}_{s}=d$ if the outcome reflects the lower judge's preference. Conversely, the cost of outcome $R$ for the lower judge is $\mathrm{w}_{\mathrm{j}} \mathrm{D}_{\mathrm{j}}$, where $\mathrm{w}_{\mathrm{j}}$ is a nonnegative weight and $\mathrm{D}_{\mathrm{j}}=|\mathrm{R}-\mathrm{J}|$, i.e., $D_{j}=0$ for any $R=J$ and $D_{j}=d$ for any $R=S C$.

Superior courts, however, may review and overturn lower court decisions. Due to lack of time or simply because few cases are appealed, superior courts may not be able to monitor every ruling, but some decisions will certainly fall under scrutiny (Songer, 


\section{Figure 1 Model of Hierarchical Pressures}

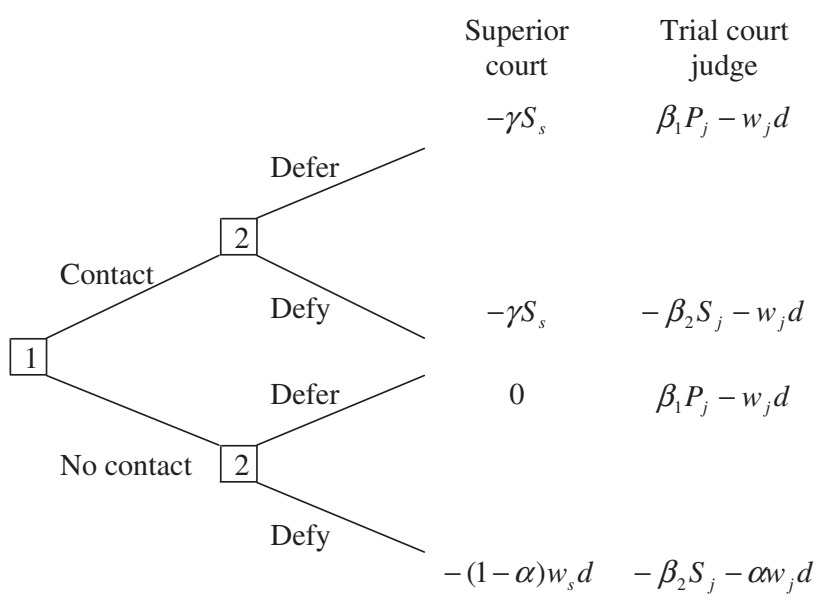

1 Superior Court's Pivotal Member

2 Trial Court Judge

Cameron, and Segal 1995). In the model, superior courts monitor lower court decisions with probability $\alpha$. Presumably, the probability of scrutiny is very high once the superior court has contacted the judge and made explicit its preferences on a case (for simplicity we assume that in such a case $\alpha=1$ ).

Career Goals. Let $\mathrm{P}_{\mathrm{j}}$ be the utility of a promotion for the lower judge given his or her progressive ambitions; $S_{j}$ the cost of being removed from office (or not reappointed) given his or her static ambitions; and $S_{s}$ the cost of being removed from office for the superior judge (all terms are nonnegative). For simplicity we assume that superior judges have only static ambitions, although assuming progressive ambitions would not substantially alter our argument.

Because judges know the details of their cases better, superior courts may allow judges some degree of interpretive discretion, just as legislators allow bureaucrats some range of discretion in their interpretation of statutes (Haire, Lindquist, and Songer 2003; Huber and Shipan 2002). But superior courts may also punish rebel judges by denying them reappointment to their posts, and they reward loyal judges by promoting them to better positions. The lower judge believes that promotions are decided by political rather than meritocratic criteria with probability $\beta_{1}$ while appointments (or reappointments) are determined by political criteria with probability $\beta_{2}$. In turn, the members of the superior court believe that improper behavior - such as pressuring a judge regarding a case-will be disclosed and punished (leading to their removal from office) with probability $\gamma$. Since $\gamma$ reflects the degree of accountability in a judicial system, we treat this parameter as constant in our case study.

Given this setup, consider the pure strategy subgame perfect equilibrium: when the superior court does not contact the lower judge, the judge is willing to defy if $w_{j} d>\frac{\beta_{1} P_{j}+\beta_{2} S_{j}}{1-\alpha}$. The main implications of the model are illustrated in Figure 2: judges distant from appellate courts are more likely to challenge their superiors, but such judges will be reluctant to do so when the probability of being overturned is high (Panels 2.1 and 2.2).

We can summarize the expectations of the model in the following hypotheses:

H1: Judges who distrust the superior court's interpretation of the law. i.e., those spatially distant from SC, are less likely to reflect its position when ruling in a case; but

H1b: As the probability of being monitored by the superior court $(\alpha)$ increases, so does the distance necessary to convince the judge to defy the appellate court.

H2: Judges who believe that superior courts are prone to manipulate judicial careers are more likely to reflect the position of sanctioning players; but

H2b: They may be less likely to defer to superior courts if they lack career ambitions.

Consider now the game from the perspective of the superior court (Figures 2.3 and 2.4). Superior judges have incentives to pressure trial courts if the courts are potentially defiant and if the risks of a scandal are low. That is, superior judges will exercise hierarchical pressures if $d>\frac{\beta_{1} P_{j}+\beta_{2} S_{j}}{(1-\alpha) w_{j}}$ and $d>\frac{\gamma S_{s}}{(1-\alpha) w_{s}}$. This structure of incentives leads to three additional hypotheses regarding strategic pressures:

H3: Superior judges will face incentives to exercise hierarchical pressures over lower judges who are spatially distant from their preferences; but

H3b: Informal pressures will be less necessary if lower judges anticipate a high probability of reversal of deviant rulings, and

H3c: Informal pressures may be less necessary if lower judges believe that superior courts are prone to manipulate judicial careers and have strong career ambitions. 


\section{Figure 2 Equilibrium Predictions for Four Configurations}

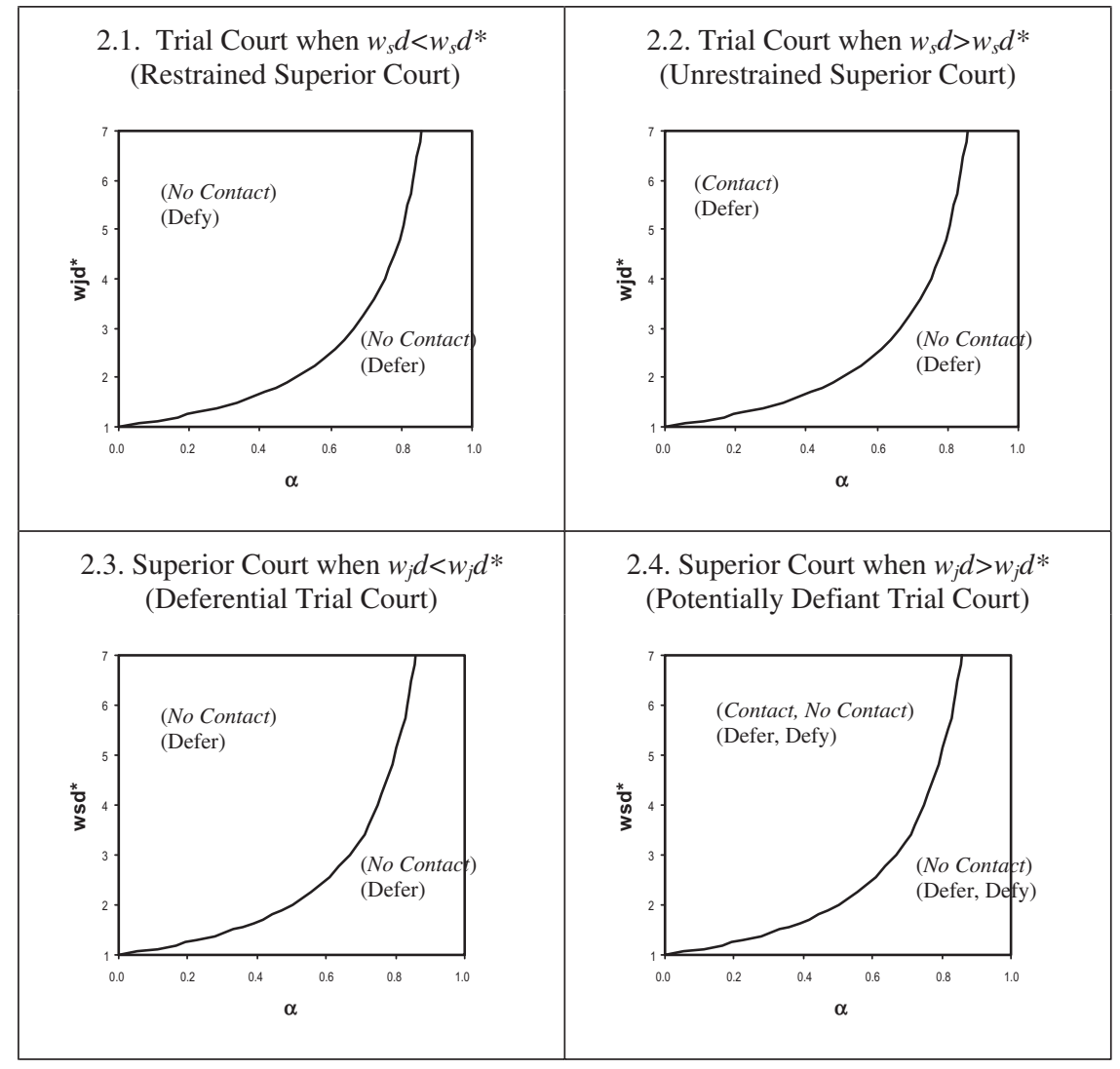

Note: Pure strategy subgame perfect equilibrium profiles are noted for each region. The superior court strategy is listed first (in italics) followed by the lower court strategy. Parameter $w_{j} d^{*}=\frac{\beta_{1} P_{j}+\beta_{2} S_{j}}{1-\alpha}$ captures the distance below which the judge always defers to the superior court (even in the absence of pressures). Parameter $w_{s} d^{*}=\frac{\gamma S_{s}}{(1-\alpha)}$ captures the distance below which the superior court has no incentive to exercise pressures over the judge. For the purposes of the illustration, the remaining values were fixed: $\beta_{1}=\beta_{2}=\gamma=.1$; $\mathrm{P}_{j}=\mathrm{S}_{\mathrm{j}}=5 ; \mathrm{S}_{\mathrm{s}}=10$. Distance range in the figures (1-7) reproduces empirical range discussed below.

\section{Judicial Institutions in Bolivia}

We explore these hypotheses using the Bolivian judicial system as a case study. Bolivia presents an interesting test for two reasons. First, the country has been marked by problems of judicial independence that are characteristic of many other Latin American cases. In the early 1990s, Gamarra noted that:

... judicial autonomy has been elusive in Bolivia. One of the most significant factors has to do with the selection of personnel. Tenure terms, selection, and promotion of judges are all tied into the complex web of patronage which characterizes the Bolivian political process. (Gamarra 1991)

Second, in the latter half of the 1990s Bolivia implemented a series of institutional reforms intended to insulate the judiciary from political pressures and to improve judicial independence. This process strength- ened the role of judicial bodies in the nomination and promotion of judges, providing a new legal environment to test our model of hierarchical pressures.

The Bolivian judiciary is led by a 12 -member Supreme Court. Until the 1995 constitutional reform, the justices were nominated by the Senate and appointed by the Chamber of Deputies. The 1995 Constitution established a five-member Judicial Council (Consejo de la Judicatura), a technical body responsible for nominating candidates for the Supreme Court, the Constitutional Tribunal, the superior district courts, and the trial courts. ${ }^{6}$ Supreme

${ }^{6}$ The presence of the Judicial Council has not fully removed political influences from the judiciary, as four of its five members are appointed by congress for six-year terms without immediate reelection (the fifth member is the chief justice). We are indebted to an anonymous reviewer for this point. 
Court justices are currently nominated by the Council and appointed by two-thirds of the congress in a joint session. ${ }^{7}$ In addition, the 1995 Constitution removed the power of judicial review from the Supreme Court and created a Constitutional Tribunal composed of five members. ${ }^{8}$

Prior to 1995, the Supreme Court nominated candidates for the superior district courts, the maximum instances of appeal in each of the country's nine departments. Based on these nominations, the Senate appointed appellate judges in each district (called vocales). Currently, the Judicial Council nominates the candidates for the superior courts, who are appointed with the vote of two-thirds of the Supreme Court justices. The number of vocales in the superior courts ranges from 20 in the department of La Paz to only five in Beni.

Bolivia is a unitary country with a single judicial hierarchy (see online appendix Table A1 on the territorial distribution and number of Bolivian judges). District judges (jueces de partido) in province-level trial courts and instructing judges (jueces de instrucción) in municipal-level courts were formerly appointed by the Supreme Court for four-year terms (with the possibility of re-appointment). After the 1995 reform, lower judges are nominated by the Judicial Council and appointed by the superior district courts; they remain in office so long as their performance is satisfactory. Table 1 summarizes the structure of nomination and appointment powers in the Bolivian system before and after the reforms of the 1990s. These reforms have given greater leverage to the superior district courts in their relationship with judges with progressive ambitions, but the reforms have potentially eroded the leverage of superior courts among judges with static ambitions. Since judges do not need to be explicitly reappointed, fear of arbitrary removal may be less relevant in shaping judicial behavior. $^{9}$

\footnotetext{
${ }^{7}$ The presence of multiple veto players in congress has delayed the appointment of the Supreme Court members. At the time the survey was conducted, only six of the 12 justices were in office (Datos 2004). In late July of 2004, President Carlos Mesa appointed six interim justices by decree, but the appointments were overturned in November by the Constitutional Tribunal.

${ }^{8}$ The Supreme Court remains the ultimate Court of Cassation.

${ }^{9}$ The absence of explicit reappointment does not mean, on the other hand, that judges can be easily dismissed. Judges must be evaluated at regular intervals by the Judicial Council, and under the new rules staying in the job is the reversionary point unless the Council recommends dismissal. At the time of this writing, the internal handbook to regulate performance evaluation (Manual Regulador del Subsistema de Evaluación del Desempeño) had not been approved by the Judicial Council.
}

\section{Data and Measurement}

The hypotheses presented above emphasize the role of subjective beliefs and expectations in shaping the relationship between superior courts and trial courts. They also underline the operation of informal procedures (such as hierarchical pressures) in judicial systems. Conventional studies of judicial behavior based on the analysis of legal cases are often unable to assess the impact of those factors. We employ survey data to address some of the related measurement problems.

Between July and September of 2003, we conducted a survey of the Bolivian judiciary, interviewing a representative sample of judges from all districts, legal areas, and organizational levels (Ames et al. 2004). ${ }^{10}$ Our sample comprises about $47 \%$ of the instructing judges, $60 \%$ of the district (partido) judges, and $45 \%$ of the superior district court vocales in the country (see online appendix 1 for a discussion of sample design). Survey data do not allow us to capture the effects of case-specific factors, but they do allow us to model the effects of career ambitions and subjective expectations on judicial decisions. The text of the questions discussed below is presented (together with their Spanish wording) in online appendix 2 .

\section{Outcomes}

Deference to Superior Courts. In order to measure our first dependent variable (the influence of superior courts on lower-level judges), we introduced two questions: "On a scale from 1 to 10 , how important are the opinions of the Superior District Court when you draft a decision?" "On a scale from 1 to 10, how important are the opinions of the Supreme Court when you draft a decision?" We also asked judges to rate, using the same scale, the relevance of the statute's text, which presumably every judge in a civil law system should rate at the top, and the relevance of precedent, a measure to disentangle diffuse deference to precedent from specific responsiveness to the superior courts. Although these questions do not tell us what judges do when confronted with actual cases, they allow us to measure general orientations (similar items were employed by Becker 1966; Fucito 2002; Howard 1981; Kitchin 1978; Klein 2002). The distribution of responses was not surprising: the average Bolivian judge declared that his or her decisions were

\footnotetext{
${ }^{10}$ The study was supported by USAID Bolivia under Cooperative Agreement No. 511-A-00-02-00184-00 (see Ames et al. 2004).
} 
TABLE 1 Judicial Nominations and Appointments in Bolivia (Before and After 1995)

\begin{tabular}{lcccc}
\hline Body & Charter & Nomination & Appointment & Term \\
\hline Supreme Court (CSJ) & 1967 & Senate & Deputies & $10+$ \\
& 1995 & JC & Congress (2/3) & $10-$ \\
Constitutional Tribunal & 1967 & (Judicial review exercised by CSJ) & \\
& 1995 & Open & Congress (2/3) & $10-$ \\
Judicial Council (JC) & 1967 & (Functions performed by Senate, CSJ) & \\
Superior District Courts (SDC) & 1995 & Open & Congress (2/3)* & $10-$ \\
& 1967 & CSJ & Senate & $6+$ \\
District judges & 1995 & JC & CSJ $(2 / 3)$ & No term \\
& 1967 & Open & CSJ & $4+$ \\
Instructing judges & 1995 & JC & SDC & No term \\
& 1967 & Open & CSJ & $4+$ \\
& 1995 & JC & SDC & No term \\
\hline
\end{tabular}

Notes: Appointments are made by simple majority of the appointing body unless otherwise specified (2/3). * The Council is chaired by the Chief Justice of the CSJ. Term indicates the length of the term in years: + immediate reelection; - reelection only allowed after one term out of office; No term indicates that judges remain in office unless dismissed by the Judicial Council. The Council has not yet agreed on a set of rules for judicial performance evaluation.

Sources: Bolivian Constitutions (1967 and 1995) and laws 1817 (1997, Judicial Council), 1836 (1998, Constitutional Tribunal), and 2650 (2004, Constitutional Reform).

highly driven by the text of the law (8.8), followed by the opinions of the Supreme Court (8.2), precedent (8.1), and, in a more distant position, by the opinions of the superior district court (7.4).

Superior Court Pressures. Hypothesis 3 refers to the behavior of superior judges in disclosing their private preferences to instructing or district judges. Capturing this type of behavior is difficult because there is no record of such informal contacts. In order to address this problem, we adopted a victimization approach to superior judge pressures. When interviewing judges, we asked: "Over the last year, have you ever been contacted by a superior judge who attempted to influence your decision in a case?" Similar items have been employed, with significant success, in public opinion studies measuring exposure to corruption (Seligson 2002b). About 9\% of all judges reported receiving pressures from their superiors over the past 12 months, with the levels of victimization ranging from over $14 \%$ among instructing judges to less than $6 \%$ among superior district judges.

\section{Independent Variables}

Policy Goals. Our first independent variable is the distance between the superior courts and the lower judges. It is worth emphasizing that distance in this context does not simply refer to the ideological gap between two players but mainly to the degree of congruence (or trust) in their respective interpretations of the law. Judges in civil law systems often do not see themselves as setting policies (they may even deem this idea as offensive) but rather as enforcing statutes. Differences in the interpretation of the statutes between rank-and-file judges and their superiors may result from ideological disagreements, but such differences are often the product of individual trajectories (career judges versus political appointees), professional demands (pragmatic versus doctrinaire views of the law), and distinct legal traditions (positivists versus natural rights proponents). In order to capture the regard of lower judges for the superior courts, we employed two general questions: "On a scale from 1 to 7, how much do you trust your Superior District Court?" and ". . . how much do you trust the Supreme Court?" These questions sought to capture the judge's confidence in the superior court's positions irrespective of the details of the cases or policy areas at stake. To simplify the interpretation of the empirical results presented in the next section, we inverted the scales to reflect distance rather than proximity. Seventy two percent of the trial court judges located themselves as professionally close to the Supreme Court (below 3 in the 7-point scale), and $68 \%$ did so with regards to the superior district courts.

In order to measure judges' fears of being overridden (parameter $\alpha$ in the model) we asked: "On a scale from 1 to 10 , how important for you is the possibility that a superior tribunal will overturn your ruling at the moment of drafting a decision?" The responses showed that the typical trial court judge 
usually feared an overturn (the mean was 8.0 in a 10 point scale).

Career Goals. The survey included a battery of questions intended to map judicial careers. Among them were: What was your job immediately prior to taking this position? For how many years would you like to stay in this job? Where would you like to go immediately after leaving this position? Figure 3 summarizes the main patterns of judicial recruitment and career ambitions in Bolivia. About $41 \%$ of the instructing judges were recruited among court officials; an additional $22 \%$, from private practice; $16 \%$ came from jobs in the public administration; and 15\% held a prior position as an instructing judge in a different court. With regards to the district judges, 19\% were recruited from among the instructing judges; $24 \%$ from private practice; $12 \%$ among public officials, and $22 \%$ among peers looking for lateral transfers. In turn, the vocales of superior district courts were mostly recruited among the district judges (64\%), private practitioners (14\%), and public officials (9\%).

Bolivian judges display a balanced distribution of progressive and static ambitions. Among the instructing judges, $52 \%$ intend to move to a partido court and another $10 \%$ hope to by pass this step and join a superior district court. In contrast, $26 \%$ display explicitly static ambitions, declaring that they intend to retire, teach law, or move to private practice after leaving office. Thirty-six percent of the district judges aspire to join the superior district court, as opposed to $46 \%$

\section{Figure 3 Judicial Careers in Bolivia: Ambitions and Recruitment Patterns}

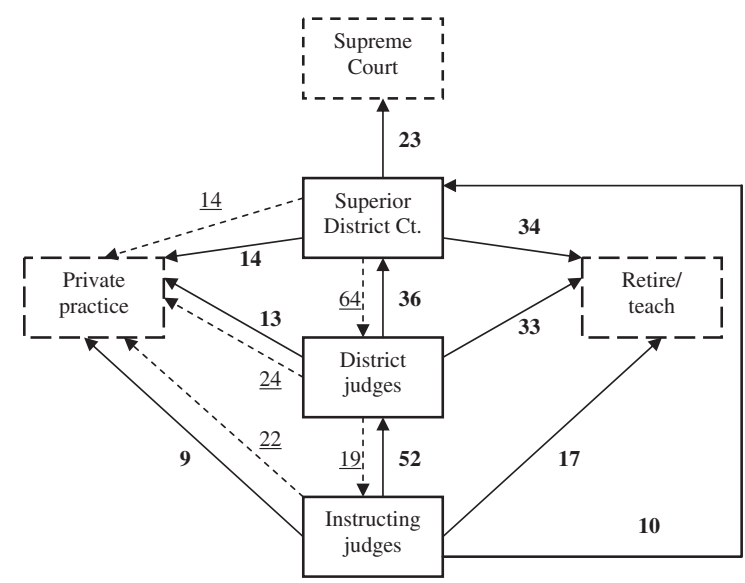

$\longrightarrow$
\[ \begin{array}{l}10 \\ \text { position) }\end{array} \text { Ambitions (Percentage of judges pursuing next position) } \] with static ambitions. In turn, $43 \%$ of the superior district vocales hope to be promoted to the Supreme Court, the Constitutional Tribunal, or the Judicial Council, while $48 \%$ want to retire or return to private practice.

We coded progressive ambitions using two dummy variables. The first variable captured the situation of the instructing or district judges who depend on the superior district court to achieve their desired promotions (including lateral transfers). The second variable captured the position of instructing or district judges who depended on the Supreme Court to become superior district vocales. Judges displaying static ambitions were coded as zero for both variables. We also asked all respondents how many years they would like to stay in their current job. This measure reflects the time horizons of judges with static ambitions and the patience of judges with progressive ambitions.

In order to capture the lower judges' concerns about political manipulation of promotions and appointments (parameters $\beta_{1}$ and $\beta_{2}$ in the model), we asked two questions: "On a scale from 1 to 7 , how much more likely do you think that judges with good political contacts are to be nominated for a superior post?" And "On a scale from 1 to 7, how much more likely do you think that judges with good political contacts are to be re-appointed to their posts [at the end of their terms]?" "11 Responses indicated that judges usually anticipated manipulation of promotions and appointments (5.8 and 5.7 respectively in a 7-point scale). In addition, we added a battery of control variables to our tests. We included a conventional measure of ideology (self-placement on a ten-point, left-right scale) and two dummies to control for criminal courts (68\% of all trial courts) and provincial courts (more isolated physically from the influence of superior district courts). ${ }^{12}$

\section{Data Analysis}

Because deference to superior courts was measured in a scale ranging from 1 to 10 , we modeled the first

\footnotetext{
${ }^{11}$ The range of the scales (1-7 or $\left.1-10\right)$ varied in different items according to the conventions employed in public opinion surveys for similar questions.

${ }^{12}$ The so-called provincial courts (juzgados de provincia) are located outside of the capital city of the department, home of the superior district court and of most lower-level courts. About 35\% of the partido courts and about $40 \%$ of the instructing courts in our sample were located in the provinces.
} 
dependent variable using regression analysis. (Since we interviewed a large proportion of the judicial population, standard errors were corrected to reflect finite population sampling.) Table 2 displays four models predicting the relevance of superior court opinions for instructing or district judges. Judges distant from the legal views of the superior courts are more reluctant to reflect their opinions in their rulings, but judges who fear reversals are strategic in anticipating the superior courts' positions (see online appendix 3 for a discussion of conditional coefficients). Two factors underscore the strategic nature of this behavior. First, this finding holds even after we control for the value assigned by different judges to legal precedent (which, not surprisingly, has a positive and significant effect in all models). Second, the same judges are also more likely to anticipate superior courts' opinions when they believe that political factors influence promotions, indicating a pattern of risk-averse behavior.

The evidence regarding hypothesis $\mathrm{H} 2 \mathrm{~b}$ is less conclusive. Judges who fear political manipulation of promotions are more likely to defer both to the Supreme Court and to the superior district courts, but there is no evidence that this effect is depressed by the lack of progressive ambition. Progressive ambition has a feeble impact on the conditional effect of political promotions both in the case of superior district courts and the Supreme Court (see online appendix Table A2). At the same time, the limited relevance of static ambitions or the fear of political removals for predicting deference to superior courts (online appendix Figure A2) is consistent with the new institutional design that has made continuation in office the default outcome for most judges (see Table 1).

To what extent are superior courts able to exercise strategic pressures over lower judges? Since our measure capturing informal contacts is dichotomous, Table 3 presents a logistic regression in which exposure to hierarchical pressures is the dependent variable. Consistent with hypothesis 3, Model 3.1 suggests that judges are more likely to suffer pressures when they are distant from the superior district court's legal views. Informal contacts seem to occur within judicial districts rather than between the Supreme Court and the trial courts. Although the variables indicating fear of reversals and progressive ambitions depending on the superior district courts approach the .1 level of significance, no other variable except being a criminal judge has a significant effect on the likelihood of suffering hierarchical pressures. However, because of the limited number of positive cases (38 judges acknowledged being victims of pressures), we developed a trimmed model including only those variables. Model
3.2 suggests that the fear of reversals may in fact be negatively related to the probability of victimization. Progressive ambition also achieves statistical significance, but the sign of the coefficient is not consistent with hypothesis $3 \mathrm{c}$.

A potential problem with the measure of distance in Models 3.1 and 3.2 is that lower judges may be less likely to trust their superiors when they are contacted improperly. If this is the case, our indicator may reflect not only professional differences between trial and superior courts, but also the consequences of hierarchical pressures. In order to disentangle those effects, we developed an alternative measure of ideological distance. Since our sample included several vocales in superior district courts (three to seven vocales in each district), we estimated the absolute distance between the ideology (left-right scale) of the judge in question and the average vocal interviewed in his or her district. The results, presented in Model 3.3, are consistent with the previous findings.

Model 3.4 includes several interactive terms. The results should be seen with caution given the large number of predictors and the limited number of cases of hierarchical pressure. Although judges who anticipate overturns still appear to be less likely targets, the conditional effect of distance only becomes significant for judges who fear reversals ( 7 or higher in the scale), which questions the strategic effect posed by hypothesis $3 \mathrm{~b}$ (see online appendix Figure A3). Not surprisingly, the models presented in Table 3 have a low predictive capacity, suggesting that informal pressures may be driven by the specific nature of the cases more than by individual characteristics. Superior courts are more likely to target lower judges if they are deciding on cases relevant enough to deserve the effort (and the risk) of an informal contact. A fully specified model should capture the interaction between individual attributes and case facts by combining survey and case data. Unfortunately, limited available information makes it impossible to undertake such a research design at this stage.

Our empirical findings support some fundamental claims: lower judges are more deferential to superior courts when they are closer to their interpretation of the law and when they fear reversals or political manipulation of promotions. In turn, superior judges are more likely to exercise pressures over trial courts when those courts are distant from their legal views and when they do not fear to be overturned. Our analysis of interactive terms, however, lent little support for the more complex strategic interactions posed by hypotheses $\mathrm{H} 1 \mathrm{~b}, \mathrm{H} 2 \mathrm{~b}, \mathrm{H} 3 \mathrm{~b}$, and $\mathrm{H} 3 \mathrm{c}$. 
TABLE 2 Influence of the Superior District Courts (SDC) and the Supreme Court (CSJ) on Lower Courts Rulings

\begin{tabular}{|c|c|c|c|c|}
\hline Variable & $\begin{array}{c}2.1 \\
\text { Deference } \\
\text { to SDC }\end{array}$ & $\begin{array}{c}2.2 \\
\text { Deference } \\
\text { to SDC }\end{array}$ & $\begin{array}{c}2.3 \\
\text { Deference } \\
\text { to CSJ }\end{array}$ & $\begin{array}{c}2.4 \\
\text { Deference } \\
\text { to CSJ }\end{array}$ \\
\hline Distance superior court (SDC) & $\begin{array}{r}-.570^{*} \\
(.075)\end{array}$ & $\begin{array}{r}-.601^{*} \\
(.224)\end{array}$ & & \\
\hline Distance Supreme Court (CSJ) & & & $\begin{array}{r}-.409^{*} \\
(.073)\end{array}$ & $\begin{array}{r}-.721^{\star} \\
(.265)\end{array}$ \\
\hline Fear of reversal & $\begin{array}{l}.210^{*} \\
(.036)\end{array}$ & $\begin{array}{r}.201^{*} \\
(.071)\end{array}$ & $\begin{array}{l}.206^{*} \\
(.031)\end{array}$ & $\begin{array}{l}.122 \\
(.069)\end{array}$ \\
\hline Distance SDC*Fear of reversal & & $\begin{array}{l}.003 \\
(.027)\end{array}$ & & \\
\hline Distance CSJ ${ }^{\star}$ Fear of reversal & & & & $\begin{array}{c}.040 \\
(.033)\end{array}$ \\
\hline Fear of political promotion & $\begin{array}{r}.252^{*} \\
(.112)\end{array}$ & $\begin{array}{l}.288^{*} \\
(.116)\end{array}$ & $\begin{array}{r}.252^{*} \\
(.085)\end{array}$ & $\begin{array}{r}.223^{\star} \\
(.089)\end{array}$ \\
\hline $\begin{array}{l}\text { Progressive ambition: } \\
\text { Depends on SDC }\end{array}$ & $\begin{array}{l}.100 \\
(.150)\end{array}$ & $\begin{array}{c}.955 \\
(.568)\end{array}$ & & \\
\hline Depends on CSJ & & & $\begin{array}{l}.163 \\
(.128)\end{array}$ & $\begin{array}{l}-.269 \\
(.776)\end{array}$ \\
\hline $\begin{array}{l}\text { Fear of political promotion } \\
\quad{ }^{\star} \text { Progressive ambition (SDC) }\end{array}$ & & $\begin{array}{c}-.145 \\
(.097)\end{array}$ & & \\
\hline $\begin{array}{l}\text { Fear of political promotion } \\
{ }^{*} \text { Progressive ambition }(\mathrm{CSJ})\end{array}$ & & & & $\begin{array}{c}.074 \\
(.125)\end{array}$ \\
\hline Fear of political removal & $\begin{array}{c}-.171 \\
(.107)\end{array}$ & $\begin{array}{c}-.184 \\
(.106)\end{array}$ & $\begin{array}{l}-.139 \\
(.082)\end{array}$ & $\begin{array}{l}-.150 \\
(.091)\end{array}$ \\
\hline Static ambition (years in post) & $\begin{array}{c}.013 \\
(.009)\end{array}$ & $\begin{array}{l}.005 \\
(.039)\end{array}$ & $\begin{array}{r}.015^{\star} \\
(.006)\end{array}$ & $\begin{array}{l}.006 \\
(.034)\end{array}$ \\
\hline $\begin{array}{l}\text { Fear of political removal } \\
{ }^{*} \text { Static ambition }\end{array}$ & & $\begin{array}{l}.001 \\
(.007)\end{array}$ & & $\begin{array}{l}.001 \\
(.006)\end{array}$ \\
\hline Relevance of Positive Law & $\begin{array}{r}.178^{*} \\
(.051)\end{array}$ & $\begin{array}{r}.177^{\star} \\
(.051)\end{array}$ & $\begin{array}{r}.094^{*} \\
(.047)\end{array}$ & $\begin{array}{l}.093^{\star} \\
(.047)\end{array}$ \\
\hline Relevance of Jurisprudence & $\begin{array}{l}.229^{\star} \\
(.041)\end{array}$ & $\begin{array}{r}.234^{\star} \\
(.041)\end{array}$ & $\begin{array}{l}.289^{\star} \\
(.039)\end{array}$ & $\begin{array}{l}.289^{\star} \\
(.039)\end{array}$ \\
\hline Ideology & $\begin{array}{l}.005 \\
(.043)\end{array}$ & $\begin{array}{l}.008 \\
(.043)\end{array}$ & $\begin{array}{c}.042 \\
(.036)\end{array}$ & $\begin{array}{c}.047 \\
(.036)\end{array}$ \\
\hline Criminal court & $\begin{array}{c}.092 \\
(.127)\end{array}$ & $\begin{array}{l}.100 \\
(.126)\end{array}$ & $\begin{array}{l}-.106 \\
(.109)\end{array}$ & $\begin{array}{c}-.104 \\
(.109)\end{array}$ \\
\hline Provincial court & $\begin{array}{c}-.061 \\
(.129)\end{array}$ & $\begin{array}{c}-.072 \\
(.127)\end{array}$ & $\begin{array}{c}.027 \\
(.109)\end{array}$ & $\begin{array}{c}.018 \\
(.111)\end{array}$ \\
\hline Intercept & $\begin{array}{c}2.907^{\star} \\
(.681)\end{array}$ & $\begin{array}{r}2.795^{\star} \\
(.919)\end{array}$ & $\begin{array}{c}3.237^{\star} \\
(.608)\end{array}$ & $\begin{array}{c}4.133^{*} \\
(.870)\end{array}$ \\
\hline $\mathrm{N}$ & 331 & 331 & 331 & 331 \\
\hline R Squared & .31 & .31 & .28 & .28 \\
\hline
\end{tabular}

Notes: OLS coefficients (standard errors). Finite population correction assumes simple random sampling without replacement within each stratum. Dependent variable is relevance of court's opinions for judge's own ruling (ten-point scale). ${ }^{*} p<.05$; two tailed. 
TABLE 3 Probability of Hierarchical Pressures over District and Instructing Judges

\begin{tabular}{|c|c|c|c|c|}
\hline Variable & 3.1 & 3.2 & 3.3 & 3.4 \\
\hline Distance superior district court (SDC) & $\begin{array}{l}.405^{*} \\
(.125)\end{array}$ & $\begin{array}{l}.355^{*} \\
(.116)\end{array}$ & & $\begin{array}{l}.001 \\
(.377)\end{array}$ \\
\hline Ideological distance SDC & & & $\begin{array}{l}.231^{\star} \\
(.101)\end{array}$ & \\
\hline Distance Supreme Court (CSJ) & $\begin{array}{l}-.129 \\
(.156)\end{array}$ & & & \\
\hline Fear of reversal & $\begin{array}{c}-.097 \\
(.060)\end{array}$ & $\begin{aligned}-.137^{\star} \\
(.060)\end{aligned}$ & $\begin{array}{l}-.116 \\
(.054)\end{array}$ & $\begin{array}{r}-.285^{\star} \\
(.144)\end{array}$ \\
\hline Distance SDC ${ }^{\star}$ Fear of reversal & & & & $\begin{array}{l}.040 \\
(.043)\end{array}$ \\
\hline Fear of political promotion & $\begin{array}{l}.090 \\
(.242)\end{array}$ & & & $\begin{array}{l}-.138 \\
(.263)\end{array}$ \\
\hline \multicolumn{5}{|l|}{ Progressive ambition: } \\
\hline Depends on SDC & $\begin{array}{l}.698 \\
(.426)\end{array}$ & $\begin{array}{l}.916^{*} \\
(.283)\end{array}$ & $\begin{array}{l}.521 \\
(.311)\end{array}$ & $\begin{array}{c}-2.409 \\
(1.540)\end{array}$ \\
\hline Depends on CSJ & $\begin{array}{l}-.060 \\
(.388)\end{array}$ & & & \\
\hline $\begin{array}{l}\text { Fear of political promotion } \\
{ }^{\star} \text { Progressive ambition (SDC) }\end{array}$ & & & & $\begin{array}{r}.541^{*} \\
(.252)\end{array}$ \\
\hline Fear of political removal & $\begin{array}{l}.330 \\
(.268)\end{array}$ & & & $\begin{array}{l}.382 \\
(.327)\end{array}$ \\
\hline Static ambition (years in post) & $\begin{array}{l}-.010 \\
(.028)\end{array}$ & & & $\begin{array}{c}-.051 \\
(.122)\end{array}$ \\
\hline $\begin{array}{l}\text { Fear of political removal } \\
{ }^{\star} \text { Static ambition }\end{array}$ & & & & $\begin{array}{l}.007 \\
(.020)\end{array}$ \\
\hline Relevance of Positive Law & $\begin{array}{l}.115 \\
(.131)\end{array}$ & & & \\
\hline Relevance of Jurisprudence & $\begin{array}{l}-.126 \\
(.104)\end{array}$ & & & \\
\hline Ideology & $\begin{array}{l}.052 \\
(.095)\end{array}$ & & & \\
\hline Criminal court & $\begin{array}{c}-.594 \\
(.284)\end{array}$ & $\begin{array}{c}-.579^{\star} \\
(.244)\end{array}$ & $\begin{array}{r}-.643^{\star} \\
(.250)\end{array}$ & $\begin{array}{l}-.509 \\
(.267)\end{array}$ \\
\hline Provincial court & $\begin{array}{l}-.211 \\
(.308)\end{array}$ & & & \\
\hline Intercept & $\begin{array}{l}-4.797 \\
(1.146)\end{array}$ & $\begin{array}{r}-2.009^{\star} \\
(.591)\end{array}$ & $\begin{array}{r}-1.479^{*} \\
(.425)\end{array}$ & $\begin{array}{c}-2.189 \\
(1.789)\end{array}$ \\
\hline $\mathrm{N}$ & 331 & 395 & 370 & 354 \\
\hline Pseudo R Squared & .07 & .05 & .03 & .09 \\
\hline
\end{tabular}

Notes: Logistic regression coefficients (standard errors). Finite population correction assumes simple random sampling without replacement within each stratum. Dependent variable is victimization in cases of hierarchical pressure.

${ }^{*} p<.05$; two tailed.

Does this pattern of behavior within the Bolivian judiciary indicate that the institutional reforms implemented in the 1990s were ultimately a failure? It is too early (and the evidence is too scant) for a definitive answer to this question. Eight years after the constitutional reform and five years after the establishment of the Judicial Council, politicians and public officials continue to try to influence judges at a greater rate than superior courts. As a counterpart to the question on hierarchical pressures, we asked judges: "Over the last year, has any politician or public official contacted you to influence your decision in a case?" About $17 \%$ of all judges had suffered political pressures, as opposed to only $9 \%$ confronting hierarchical pressures. 


\section{From Strategic Defection to Strategic Compliance}

Our analysis underscores the need to understand the strategic behavior of lower courts in new democracies. Although recent studies of judicial independence have emphasized strategic behavior in supreme courts and in constitutional tribunals, our work shows that strategic considerations also drive the decisions of lower courts in new democracies under civil law systems. For instance, Helmke (2002, 2003) argued that the Argentine Supreme Court has followed a logic of "strategic defection," responding to the needs of the executive when the president is strong but questioning his policies when the president becomes a lame duck (see also Iaryczower, Spiller, and Tommasi 2002; Larkins 1998; Scribner 2003). In a similar way, lowerlevel courts comply strategically with the interpretation of the law preferred by superior courts. Judges will respond to the preferences of their superiors not only when they fear reversals but also when they fear the manipulation of careers. For instance, a recent study of courts in Central America showed that criminal judges are concerned about protecting their independence not only from politicians, but also from the pressures of the mass media and of their superiors in the judicial hierarchy (Ramos Rollón 2004).

Our model provides a useful framework to address problems of strategic compliance across legal systems. Like Haire, Lindquist, and Songer (2003), we find that the level of agreement between the legal views of the superior and the trial courts is a significant predictor of the principal-agent interaction. And much like Ashenfelter, Eisenberg, and Schwab (1995), we find that the ideology of the individual judges per se has little relevance for the daily work of trial courts. But in contrast to Klein and Hume, who argued that in the United States, fears of reversal do not drive lower court compliance, we found that Bolivian judges fearing reversals are more likely to defer to superior courts (Klein 2002; Klein and Hume 2003).

Some of the key findings in our study indicate that judges' beliefs and expectations (such as the fear of reversals or political manipulation of careers) are important explanatory factors of judicial behavior. Because studies of judicial decision making have typically focused on court cases as their units of analysis, they have been ill-equipped to measure individual career ambitions and the judges' subjective perceptions of superior courts (e.g., Cohen 1991, fns. 13 and 23). The use of extensive survey research can address some of those problems. However, two major challenges lie ahead. The first challenge is the development of standard survey items to measure judicial behavior and legal attitudes across legal systems. The second is the articulation of research designs able to integrate case-level information based on legal analysis with judge-level information based on survey data.

\section{Acknowledgments}

We are indebted to Christopher Bonneau, Daniel Brinks, Gretchen Helmke, Sebastian Saiegh, and the JOP readers for their valuable comments. We would like to thank The United States Agency for International Development for its generous support of the data collection in this project. An earlier version of this paper was presented at the 2004 meeting of the Latin American Studies Association.

Manuscript submitted on 2 February 2005

Manuscript accepted for publication 7 September 2005

\section{References}

Ames, Barry, Aníbal Pérez-Liñán, Mitchell A. Seligson, and Daniel Moreno Morales. 2004. Elites, Instituciones y el Público: Una Nueva Mirada a la Democracia Boliviana. La Paz: Universidad Católica Boliviana.

Ashenfelter, Orley, Theodore Eisenberg, and Stewart J. Schwab. 1995. "Politics and the Judiciary-the Influence of Judicial Background on Case Outcomes." Journal of Legal Studies 24 (2): 257-81.

Becker, Theodore L. 1966. "A Survey Study of Hawaiian Judges: The Effect on Decisions of Judicial Role Variations." The American Political Science Review 60 (3): 677-80.

Benesh, Sarah C., and Malia Reddick. 2002. "Overruled: An Event History Analysis of Lower Court Reaction to Supreme Court Alteration of Precedent.” Journal of Politics 64 (2): 534-50.

Brace, Paul R., and Melinda Gann Hall. 1997. "The Interplay of Preferences, Case Facts, Context, and Rules in the Politics of Judicial Choice." Journal of Politics 59 (4): 1206-31.

Brent, James. 2003. "A Principal-Agent Analysis of U.S. Courts of Appeals Responses to Boerne v. Flores." American Politics Research 31 (5): 557-70.

Chavez, Rebecca Bill. 2003. "The Construction of the Rule of Law in Argentina: A Tale of Two Provinces." Comparative Politics 35 (4): 417-37.

Cohen, Mark A. 1991. "Explaining Judicial Behavior or What's 'Unconstitutional' about the Sentencing Commission?" Journal of Law, Economics, \& Organization 7 (1): 183-99.

Datos. 2004. "Relaciones Extrañas.” Datos, June, 18-21.

David, René, and John E. C. Brierley. 1978. Major Legal Systems in the World Today. New York: The Free Press.

Epstein, Lee, and Jack Knight. 1998. The Choices Justices Make. Washington: CQ Press. 
Fucito, Felipe. 2002. Podrá cambiar la Justicia en la Argentina? Buenos Aires: Fondo de Cultura Económica.

Gamarra, Eduardo A. 1991. The System of Justice in Bolivia: An Institutional Analysis. Vol. 4, Monografías. Miami: Center for the Administration of Justice-Florida International University.

Haire, Susan B., Stefanie A. Lindquist, and Donald R. Songer. 2003. "Appellate Court Supervision in the Federal Judiciary: A Hierarchical Perspective." Law \& Society Review 37 (1): 143-67.

Hall, Melinda Gann. 1992. "Electoral Politics and Strategic Voting in State Supreme Courts." Journal of Politics 54 (2): 427-46.

Hall, Melinda Gann. 2001. "State Supreme Courts in American Democracy: Probing the Myths of Judicial Reform." American Political Science Review 95 (2): 315-30.

Helmke, Gretchen. 2002. "The Logic of Strategic Defection: CourtExecutive Relations in Argentina under Dictatorship and Democracy.” American Political Science Review 96 (2): 291-304.

Helmke, Gretchen. 2003. "Checks and Balances by Other Means: Strategic Defection and Argentina's Supreme Court in the 1990s." Comparative Politics 35 (2): 213-30.

Hilbink, Lisa. 2003. "An Exception to Chilean Exceptionalism? The Historical Role of Chile's Judiciary." In What Justice? Whose Justice? Fighting for Fairness in Latin America, eds. S. E. Eckstein and T. P. Wickham-Crowley. Berkeley: University of California Press, pp. 64-97.

Howard, J. Woodford. 1981. Courts of Appeals in the Federal Judicial System. Princeton: Princeton University Press.

Huber, John D., and Charles R. Shipan. 2002. Deliberate Discretion? The Institutional Foundations of Bureaucratic Autonomy. Cambridge: Cambridge University Press.

Iaryczower, Matías, Pablo T. Spiller, and Mariano Tommasi. 2002. "Judicial Independence in Unstable Environments, Argentina 1935-1998.” American Journal of Political Science 46 (4): 699-716.

Kitchin, William I. 1978. Federal District Judges: An Analysis of Judicial Perceptions. Baltimore: Collage Press.

Klein, David E. 2002. Making Law in the United States Courts of Appeals. Cambridge: Cambridge University Press.
Klein, David E., and Robert J. Hume. 2003. "Fear of Reversal as an Explanation of Lower Court Compliance." Law \& Society Review 37 (3): 579-606.

Larkins, Christopher. 1998. "The Judiciary and Delegative Democracy in Argentina." Comparative Politics 30 (4): 423-42.

Merryman, John Henry. 1985. The Civil Law Tradition. Stanford: Stanford University Press.

Ramos Rollón, Maria Luisa. 2004. La Justicia Vista por los Jueces: Diagnostico del Funcionamiento de los Sistemas de Justicia Centroamericanos. Salamanca: Universidad de Salamanca.

Ramseyer, J. Mark, and Eric B. Rasmusen. 2001. "Why Are Japanese Judges so Conservative in Politically Charged Cases?" American Political Science Review 95 (2): 331-44.

Scribner, Druscilla. 2003. "Sincere and Strategic Judicial Behavior on the Chilean Supreme Court.” Paper presented at annual conference of the Midwest Political Science Association.

Seligson, Mitchell A. 2002a. Auditoría de la Democracia: Ecuador. Quito: Ediciones CEDATOS.

Seligson, Mitchell A. 2002b. "The Impact of Corruption on Regime Legitimacy: A Comparative Study of Four Latin American Countries." Journal of Politics 64 (2): 408-33.

Songer, Donald R., Charles M. Cameron, and Jeffrey A. Segal. 1995. "An Empirical-Test of the Rational-Actor Theory of Litigation." Journal of Politics 57 (4): 1119-29.

Songer, Donald R., Jeffrey A. Segal, and Charles M. Cameron. 1994. "The Hierarchy of Justice: Testing a Principal-Agent Model of Supreme-Court Circuit-Court Interactions." American Journal of Political Science 38 (3): 673-96.

Tyler, Tom R. 2001. "Public Trust and Confidence in Legal Authorities: What do Majority and Minority Group Members Want from the Law and Legal Institutions?" Behavioral Sciences and the Law 19 (2): 215-35.

Aníbal Pérez-Liñán is assistant professor, University of Pittsburgh, PA 15260. Barry Ames is Andrew W. Mellon professor of comparative politics, University of Pittsburgh, PA 15260. Mitchell A. Seligson is Centennial professor of political science, Vanderbilt University, Nashville, TN 37325. 